\title{
Contamination of pigs by Yersinia enterocolitica in the abattoir flowchart and its relation to the farm
}

\section{Lauren Machado Moreira ${ }^{1}$ Camile Milan $^{1}$ Thaís Gonçalves Gonçalves $^{1 *}$ (iD Celina Nunes Ebersol $^{1}$ Helenice Gonzalez de Lima ${ }^{1}$ Claudio Dias Timm}

${ }^{1}$ Faculdade de veterinária, Universidade Federal de Pelotas (UFPel), 96010-900, Campus Capão do Leão, Pelotas, RS, Brasil. E-mail: thaais.g@hotmail.com. *Corresponding author.

ABSTRACT: The research intends to detect sources of contamination by Yersinia enterocolitica in the abattoir flowchart and endeavors to study its relation with the contamination in the farm. For this purpose, sixty pigs were followed up. In order to carry out the study, samples of faeces were collected from the animal farm, where the animals were originally kept and from the abattoir, directly from the animal's rectum, after desensitization. Additionally, samples were also collected from the carcass, after passage into the hair removal machine, after evisceration, prior to entry into the cold chambre, from the jowls, and water of the scald tank, before the commencement of the abattoir as well as after the passage of the animals. Further, the isolates were obtained through microbiological analyzes, upon being identified by PCR and compared via rep-PCR. Basically, Yersinia enterocolitica was isolated from three bays in the original farm (20\%) and from 20 samples $(6.67 \%)$, obtained in the abattoir flowchart. Comparison made via rep-PCR revealed that the contaminated pigs on the farm could carry the microorganism to different points in the abattoir flowchart. However, apart from the farm, other sources of the contamination werereported to be more frequent and diverse. Indeed, the chins and the carcass at the entrance of the cold chamber were identified as the most critical points. Therefore, we concluded that Y. enterocolitica present in the gastrointestinal tract of pigs on the farm, cannot be eliminated throughout theabattoir flowchart and remain in the chambers intended for the cold room.

Key words: slaughterhouse, public health, swine breeding.

\section{Contaminação de suínos por Yersinia enterocolitica no fluxograma} de abate e sua relação com a granja

RESUMO: O objetivo deste estudo foi detectar fontes de contaminação por Yersinia enterocolitica no fluxograma de abate e sua relação com a contaminação na granja. Sessenta suínos foram acompanhados. Foram coletadas amostras de fezes dos animais na granja de origem e durante o abate, diretamente do reto, após a insensibilização. Também foram coletadas amostras da carcaça após a passagem na depiladeira, após a evisceração, antes da entrada na câmara fria, da papada e da água do tanque de escaldagem antes de iniciar o abate e após a passagem dos animais. Os isolados foram obtidos através de análises microbiológicas, identificados por PCR e comparados através de repPCR. Yersinia enterocolitica foi isolada de três baias na granja de origem (20\%) e de 20 amostras (6,67\%) obtidas no fluxograma de abate. Após a rep-PCR, observou-se que os suínos contaminados na granja podem carrear o micro-organismo para diferentes pontos do fluxograma de abate. No entanto, outras fontes de contaminação que não a granja são mais frequentes e diversas. A papada e a carcaça na entrada da câmara fria são os pontos mais críticos. Conclui-se que Y. enterocolitica presente no trato gastrointestinal de suínos na granja pode não ser eliminada ao longo de todo o fluxograma de abate e permanecer na carcaça destinada à câmara fria.

Palavras-chave: abatedouro-frigorífico, saúde pública, suinocultura.

\section{INTRODUCTION}

In the last decade, the world production of pork, one of the most important sources of animal protein, has increased by an average of $1.6 \%$ per year (USDA, 2017). Apart from having high percentages of proteins, vitamins, and minerals, the surrounding environment of the pork is highly conducive for bacterial development, including pathogenic bacteria, due to which it becomes a potential vehicle for Foodborne Diseases (DTA) (CDC, 2016).

Among the various pathogens responsible for foodborne diseases, Yersinia enterocolitica is a pathogen that develops predominantly in food infections in humans (DRUMMOND et al., 2012), with its major effect being acute enteritis, especially in children. Additionally, this bacterium may also lead to erythema nodosum, arthritis, mesenteric 
lymphadenitis, and pseudoappendicitis (LEIVA et al., 2018). Further, a close analysis of the pathogenicity mechanisms of Yersinia enterocolitica revealed that it is highly complex and involved various factors. Essentially, for infection to occur, the presence of the virulence plasmid called $\mathrm{pYV}$, in addition to, at least, two chromosomal factors called ail, reported only in pathogenic strains, and inv, present in both pathogenic and non-pathogenic strains, is highly imperative (WANNET et al., 2001).

Upon considering both healthy and diseased individuals, this bacterium is mainly detected in the intestines of different animal species. Among the various carriers of this pathogenic $Y$. enterocolitica, swine is one of the important reservoirs of serotypes of this pathogen, with most commonly involved in human infection, thereby dwelling in the oral cavity, tongue, tonsils, and lymph nodes and excreted in the faeces (NESBAKKEN et al., 2003; GERMANO \& GERMANO, 2015). Moreover, it has been anticipated that the basic reason behind the various cases reported for human yersiniosis is the consumption of contaminated raw pork or malcozidae (EFSA, 2017).

The presence of $Y$. enterocolitica in the products of porcine origin has been reported by several authors such as BOLTON et al. 2013, BONARDI et al. 2013, VAN DAMME et al. 2013, BLAGOJEVIC \& ANTIC, 2014; LAUKANNEN et al. 2014, including reports from Brazil (PAIXÃO et al., 2013, SABA et al., 2013). Additionally, it has been highlighted that $Y$. enterocolitica is one of the bacteria that can be inserted in the slaughter line by the pig itself (BORCH et al.,1996). Therefore, with the intention of throwing more light onto the necessary measures required for restraining foodborne diseases from spreading extensively, the present research aimed to detect sources of contamination by $Y$. enterocolitica in the abattoir flowchart and its relation with the contamination in the farm.

\section{MATERIALS AND METHODS}

For carrying out the investigation, 60 pigs from 15 bays, present in a fullcycle farm located in the south of Rio Grande do Sul were randomly selected, identified, and monitored during slaughter in a legally established abattoir, registered and inspected by the Inspection Division Sanitary of Products of Animal Origin of the Department of Agriculture, Livestock, and Irrigation of Rio Grande do Sul. In this farm, four pigs from each bay were sampled. Further, for $Y$. enterocolitica research in the interior of the bays two weeks before the loading of the animals for slaughter, stool samples were collected by disposables use by the researchers, who walked in different directions into the bays. After, the material were collected with sterile swabs from the disposables, totaling three samples per bay. Subsequently, the collected samples were sent for analysis in Cary Blair transport medium (Himedia, India) by pacing them in ice-isothermal box. From the slaughter flowchart (Figure 1), four animals from each bay were followed, and the collection of the samples was carried out in the following way: (1) stool was collected after desensitization, by introducing sterile swab in the rectum of the animals; (2) the samples were collected after shaving, by rubbing a sterile swab in an area of $100 \mathrm{~cm}^{2}$, delimited by sterile stainless steel template on the outer surface of the carcass, being $15 \mathrm{~cm}$ from the line of the back and from the $5^{\text {th }}$ rib; (3) for collecting the samples once the abdominal cavity was opened, the sterile swabs were rubbed in an area of $100 \mathrm{~cm}^{2}$, delimited by sterile stainless steel template on the inner surface of the carcass, which is $10 \mathrm{~cm}$ from the joint of ribs with the vertebrae and from the $5^{\text {th }}$ rib; (4) immediately before the entry of the carcass into the cold chamber, the samples were collected by the friction of a sterile swab on the outer surface of the carcass in an area of $100 \mathrm{~cm}^{2}$, delimited by sterile stainless steel jig, which is $15 \mathrm{~cm}$ from the line of the back and from the $5^{\text {th }}$ rib; and (5) samples from the jowl were collected, by friction of a sterile swab on the inner surface of the jowl. Samples of water from the scalding tank were also collected, in sterile glass vials with an approximate volume of $50 \mathrm{~mL}$, before beginning the slaughter and after the passage of the animals.

Further, for isolating $Y$. enterocolitica, swabs with the samples were seeded in MacConkey agar (Acumedia, Lansing, USA). Moreover, after incubating for 24 hours at $37{ }^{\circ} \mathrm{C}$, three negative lactose colonies were seeded in Brain and Heart Infusion (BHI, Acumedia). Subsequently, the samples were incubated once again at $37{ }^{\circ} \mathrm{C}$ for 24 hours and were mixed with $20 \%$ glycerol for stock maintenance at $-70{ }^{\circ} \mathrm{C}$. However, when needed, the isolates were recovered from BHI at $37{ }^{\circ} \mathrm{C}$ for 24 hours. Conversely, the extraction of the DNA of the isolates were carried out using the protocol described by SAMBROOK \& RUSSEL (2001). Initially, the pellet obtained upon centrifuging $1.0 \mathrm{ml}$ of $\mathrm{BHI}$ culture, was resuspended in $100 \mu \mathrm{l}$ of STES buffer $(0.2$ M Tris- $\mathrm{HCl}, 0.5 \mathrm{M} \mathrm{NaCl}, 0.1 \%$ SDS (w/v), $0.01 \mathrm{M}$ EDTA, pH 7.6]. Subsequently, $50 \mu \mathrm{L}$ of glass beads and $100 \mu \mathrm{L}$ of phenol/chloroform was added, which was then homogenized for $1.0 \mathrm{~min}$ and centrifuged at 


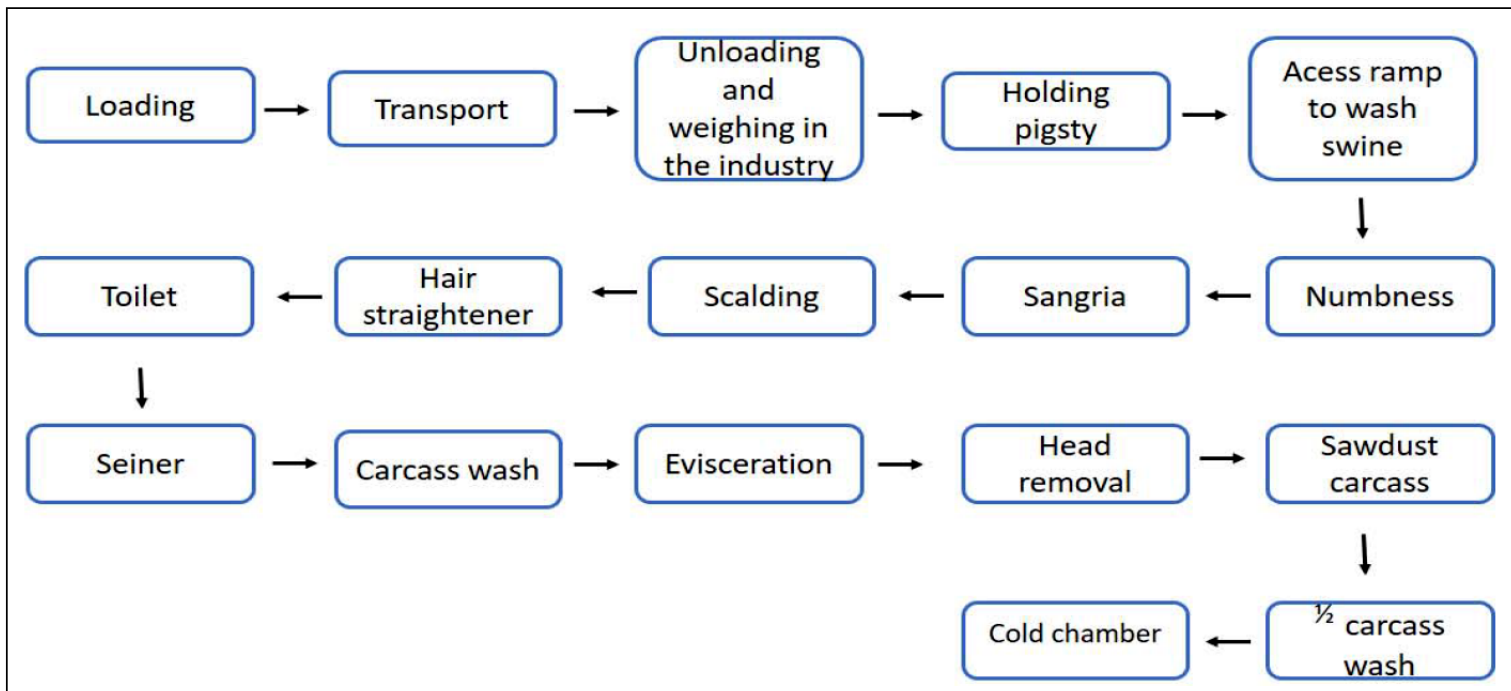

Figura 1 - Swine slaughter flowchart.

$13,000 \mathrm{~g}$ for $5.0 \mathrm{~min}$. The resulting supernatant was then collected and precipitated in 2.0 volumes of absolute ethanol and 0.1 volume of $5.0 \mathrm{M} \mathrm{NaCl}$ at -70 ${ }^{\circ} \mathrm{C}$ for $30 \mathrm{~min}$. The solution obtained was centrifuged at $13,000 \mathrm{~g}$ for $20 \mathrm{~min}$, and the supernatant, obtained after centrifugation, was discarded, and the pellet obtained was washed with $70 \%$ ethanol. Eventually, the elution was done in $40 \mu$ of elution buffer $(10 \mathrm{mM}$ Tris- $\mathrm{HCl}, 1.0 \mathrm{mM}$ EDTA, $\mathrm{pH} 7.4)$, with the extracted DNA being stored at $-70^{\circ} \mathrm{C}$.

With the aim of identifying $Y$. enterocolitica, a duplex - PCR was performed by employing procedure mentioned by WANNET et al. (2001). According to this procedure, each $25 \mu \mathrm{L}$ of the reaction mixture contained the specific primers for the ail and $16 S$ rRNA genes at concentrations of $160 \mathrm{nM}$ and $80 \mathrm{nM}$, respectively; $200 \mu \mathrm{M}$ of each nucleotide; $0.5 \mathrm{U}$ of Taq DNA polymerase; 1x buffer; $2 \mu \mathrm{l}(20 \mathrm{ng})$ of DNA. Further, the amplification was carried out at $94{ }^{\circ} \mathrm{C}$ for $5 \mathrm{~min}$, followed by 36 cycles of $94{ }^{\circ} \mathrm{C}$ for $45 \mathrm{sec}, 62{ }^{\circ} \mathrm{C}$ for $45 \mathrm{sec}$, and $72{ }^{\circ} \mathrm{C}$ for $45 \mathrm{sec}$, with the final extent being performed at $72{ }^{\circ} \mathrm{C}$ for $7 \mathrm{~min}$. Moreover, the products of the PCR were stained with GelRed, and the electrophoresis was performed on $1.5 \%$ agarose gel.

In order to compare the obtained molecular profiles of $Y$. enterocolitica, rep-PCR was performed by using the primer (GTG) 5 (VERSALOVIC et al., 1994). Further, the conditions under which the rep-PCR was carried out follows as, $2.5 \mu \mathrm{l}$ DNA, $2.0 \mu \mathrm{l}$ primer (5'-GTGGTGGTGGTGGTG-3 ‘), $12.5 \mu$ L Master Mix
(Sigma Aldrich, USA), and $8.0 \mu \mathrm{l}$ water were used for obtaining the reaction volume. Conversely, for the amplification, a cycle of $94^{\circ} \mathrm{C}$ for $5 \mathrm{~min}, 30$ subsequent cycles of $95^{\circ} \mathrm{C}$ for $30 \mathrm{~s}, 45^{\circ} \mathrm{C}$ for $1 \mathrm{~min}$ and $60^{\circ} \mathrm{C}$ for $5 \mathrm{~min}$, and finally a cycle of $60{ }^{\circ} \mathrm{C}$ for $16 \mathrm{~min}$, was carried out. Moreover, to visualize the band patterns of the different amplified regions in the genome, the rep-PCR products were stained with GelRed and electrophoresed on a $2.0 \%$ agarose gel.

\section{RESULTS AND DISCUSSION}

The $Y$. enterocolitica was successfully isolated from three $(20 \%)$ of the 15 bays investigated and $20(6.67 \%)$ of the 300 samples collected during the slaughter flowchart (Table 1). According to BHADURI (2005), the pigs are capable of carrying $Y$. enterocolitica for long periods, in their oropharynx (tonsils) and intestinal tract, without presenting any clinical signs, with the pervasiveness of the bacteria ranging from $35 \%$ to $70 \%$ in finishing pigs.

In batch 12, the strain isolated from the bay in which this batch was on the farm, manifested band pattern in the rep-PCR, which was indistinguishable from the isolate obtained from the rectum of the animals of lot 4.0 after desensitization, which implies that the pigs in this batch came from the contaminated farm. Additionally, animals of lot 2.0 also presented an isolate, obtained from the carcass surface after evisceration, which was indistinguishable from the strain isolated on the farm, which in turn led 
Table 1 - Presence of Yersinia enterocolitica on the farm and on the swine slaughter flowchart.

\begin{tabular}{|c|c|c|c|c|c|c|c|c|}
\hline Lots & Farm & Initial Water & Challenge a & PD & PE & $\mathrm{EC}$ & Dewlap & Final Water \\
\hline 1 & - & - & - - - & - - - & - - - & - - - & - - - & - \\
\hline 2 & + & - & - - - & ++-- & -+- & --+ & --+- & - \\
\hline 3 & - & - & - . - - & - - - & - . - - & $+\ldots$ & - - - & - \\
\hline 4 & - & - & $+\ldots$ & - . - - & - . - - & - . - . & - . - . & - \\
\hline 5 & - & - & - - - & +--- & - - - & ---+ & -++- & - \\
\hline 6 & - & - & - - - & --+- & --+ & - . - & $+\ldots$ & - \\
\hline 7 & - & - & - - - - & - - - & - - - - & - - - & - - - - & - \\
\hline 8 & - & - & - - - - & - - - - & - - - & - - - & - - - - & - \\
\hline 9 & - & - & - - - - & - - - - & - - - - & - - - & - - - - & - \\
\hline 10 & - & - & - - - - & - - - - & - - - & - - - & - - - & - \\
\hline 11 & - & - & - - - - & - - - - & - - - - & - - - & --- & - \\
\hline 12 & + & - & ---+ & --+ & -+- & ---+ & +--+ & - \\
\hline 13 & - & - & - . - & - - - & - - - & $-\cdots$ & $-\cdots$ & - \\
\hline 14 & + & - & - . - & - - - & - . - & - . - & - . - & - \\
\hline 15 & - & - & - - - - & - - - - & - - - & - - - & - - - - & - \\
\hline
\end{tabular}

${ }^{a}$ In the columns where four symbols appear ( + or -$)$, each corresponds to a pig. The order of the animals is the same across the board Absence of $Y$. enterocolitica (-); presence of $Y$. enterocolitica $(+)$; $\mathrm{PD}=$ Post-shaver; $\mathrm{PE}=$ Post-evisceration; $\mathrm{EC}=\mathrm{Cold}$ chamber input.

to the conclusion that pigs in this lot were carrying $Y$. enterocolitica, as well as the evisceration procedures, were inadequate thereby leading to the contamination of the internal surface of the carcass. On the contrary, the isolates obtained from the samples collected, in the slaughter flowchart of the animals from lot 2.0, did not exhibit the band pattern similar to those obtained from the isolates of the stool samples collected from the same lot 2.0 but in the bay, that is, when the lot was on the farm. This observation implied that its origin was other sources of contamination during processing. Similarly, none of the animals in lot 14, from whose faeces $Y$. enterocolitica was isolated on the farm, presented the microorganism in the feces at the moment of slaughter, showing that the feces contamination in the stall is from other animals from the same lot.

Upon analyzing the samples of the rectum, two animals, one from a positive bay and one from a negative bay, were identified to have $Y$. enterocolitica contamination. Notably, not all animals from stalls were contaminated with $Y$. enterocolitica; although, this bacterium was present in their rectum, which demonstrated that either these animals were not contaminated or were not excreting the microorganism at the time of collection. Conversely, an animal contaminated with $Y$. enterocolitica came from a negative bin. The most probable reason for this observation could be either impossibility of isolating
$Y$. enterocolitica from the faeces or the non-excretion of the bacteria, even if contaminated, at the time of slaughter, due to the stress to which it was subjected, during transport and/or fasting, for excreting the bacteria. Additionally, the small number of isolates, obtained from the faeces collected from the rectum of the animals $(2 / 20)$, in relation to the isolates, obtained elsewhere in the slaughter flow chart $(18 / 20)$, indicated that even though the contamination in the abattoir, from the carrying animals, could be a possible source of contamination, but it is a source, which is of less importance than the other sources reported throughout the slaughter flowchart. However, the diversity of band patterns obtained with rep-PCR suggested a wide variety of sources of contamination, thereby making its identification difficult.

From the carcass surface, five isolates (25\%) were obtained, after passage through the epilator. According to LASSOK \& TENHAGGEN (2013), the scalding stage performed immediately but prior to depilation, apart from facilitating hair removal, may also contribute to the reduction of the microbial load present on the skin. Further, as stated by BOLTON (2013), the temperature between $57^{\circ} \mathrm{C}-62^{\circ} \mathrm{C}$ was sufficient to inactivate $Y$. enterocolitica in the scald tank. Conversely, as perBrazilian legislation, the scalding of pigs should be carried out with water at a temperature that falls in the range of $62{ }^{\circ} \mathrm{C}$ to $72{ }^{\circ} \mathrm{C}$, for two to seven minutes (MAPA, 1995). Despite, the scalding water 
was not exchanged during the slaughter of animals, belonging to the same batch, the samples from the scald tank were investigated, which in turn revealed that $Y$. enterocolitica contamination was absent in all the analyzed samples. However, depilation step was contemplated as a critical point, since the contamination of the carcass may occur through the secretions excreted by carrier animals from their oral cavity or gastrointestinal tract. Possibly, if the microorganism were excreted by the pigs during slaughtering, then at the moment of swine removal for the elimination of hairs, extravasation of fecal matter leading to superficial contamination of the carcass might have transpired (BORCH et al., 1996). However, no strain isolated from the rectum of the animals manifested similarity with the strains isolated from the carcass surface after this stage, indicating that possibly cross-contamination occurred with strains from other pig lots which persisted in the equipment due to inefficient hygienic-sanitary management conditions or during the depilation of toilet, performed manually, through contaminated handlers. Apart from this, $Y$. enterocolitica was also isolated from the carcass surface samples after evisceration. The isolation was basically carried out from three $(15 \%)$ samples. Subsequently, the occlusion of the rectum was performed with nylon seal in the accompanying refrigerator. Principally, the plastic bags were utilized for the occlusion of the rectum, as it is a highly effective method of closing the rectum because ineffectual closing of the seal may lead to the contamination of the carcass with fecal contents (LAUKANNEN et al. 2010). These authors further a difference of $10 \%$ to $0.8 \%$ in the contamination of the carcass at this stage, upon comparing the rectum occlusion carried out in two different slaughterhouses, by only sealing and by utilizing the plastic bag, respectively. However, according to the Brazilian legislation (MAPA, 1995), the body responsible for the establishment of its adoption or not, the use of a plastic bag in the involvement of the rectum is not mandatory. Further, in the rep-PCR analysis, the isolate of animal 2.0, from batch 2.0, obtained at this stage was indistinguishable from the strain isolated from the carcass surface after the epilator, indicating that the operations were ineffective in the elimination of the microorganism in this case.

With the establishment of the occurrence of the contamination, the most plausible explanation for its appearance would be given by bringing to light that the highest number of isolates, corresponding to $30 \%$ (6/20) of the positive samples of the $Y$. enterocolitica collected in the slaughter flowchart were obtained from the jowls. Y. enterocolitica is commonly reporte in the swine oral cavity, especially in the submandibular, tonsil, tongue, and pharynx lymph nodes, with jowls being the region close to the above mentioned sites. Moreover, the presence of gill in the close proximity of all the positions or sites mentioned above possibly explains the greater isolation of the $Y$. enterocolitica from the gill, thereby validating the suggested explanation for the contamination (NESBAKKEN et al., 2003; PAIXÃO et al., 2013). Additionally, another possible reason of contamination would be a procedural failure during the inspection of the submandibular lymph nodes, which in turn could lead to the dissemination of the bacteria through the utensils used or the hands of the inspecting agents.

Upon analyzing the samples from the surface of the carcass prior to entry into the cold chamber, it was established that 20\% (4/20) of the isolates of $Y$. enterocolitica were obtained from the samples collected during the slaughter flowchart. Further, rep-PCR analysis led to the observation that the strain isolated from the carcass surface of animal 4.0 from lot 12 was indistinguishable from the isolates obtained from the rectum of the same animal and the stool sample from the bay, to which the batch belongs on the farm and presented the same pattern of bands, as commented previously. These results illustrated that the contamination which occurred in the farm can prevail throughout the slaughter processing, and eventually endures in the final product. Results also clarified that the adoption of the measures of good practices in the slaughterhouse was ineffective in eliminating the microorganism. Thus, the presence of $Y$. enterocolitica in this stage of the process proves to be critical, since this microorganism being psychrotrophic, multiples at low temperatures and remains viable in foods even after long periods of refrigeration (LAUKANNEN et al., 2014).

\section{CONCLUSION}

Conclusively, the entry into the cold chamber was ascertained to be the most critical point of control throughout the slaughtering process; although, the jowls bacteria were isolated in a greater frequency, thereby indicating that dispersion of the microorganism might have occurred during the slaughter line. Additionally, in the abattoir, the existence of $Y$. enterocolitica isolates from pigs hailing from the farm was confirmed. However, the farm was not amongst the most frequent sources of contamination; although, the presence of $Y$. enterocolitica in the farm refers to the risk of not being getting eliminated throughout the 
entire slaughter flowchart and prevailing in the cold chamber, thereby contaminating the final product and posing a risk to public health.

\section{ACKNOWLEDGEMENTS}

The presente work was carried out with the Coordenação de Aperfeiçoamento de Pessoal de Nível Superior (CAPES), Brasil - Finance code 001.

\section{DECLARATION OF CONFLICT OF INTERESTS}

The authors declared no potential conflicts of interest with respect to the research, authorship, and/or publication of this article.

\section{AUTHORS' CONTRIBUTIONS}

All authors contributed equally for the conception and writing of the manuscript. All authors critically revised the manuscript and approved of the final version.

\section{REFERENCES}

BHADURI, S.; et al. Prevalence of pathogenic Yersinia enterocolitica strains in pigs in the United States. Applied and Environmental Microbiology, v.71, $\mathrm{n}^{\mathrm{o}} .11$, p.7117-7121, 2005. Available from: $<$ https://aem.asm.org/content/71/11/7117>. Accessed: Dec. 14, 2018. doi: 10.1128/AEM.71.11.7117-7121.2005.

BLAGOJEVIC, B.; ANTIC, D. Assessment of potential contribution of official meat inspection and abattoir process hygiene to biological safety assurance of final beef and pork carcasses. Food Control. v.36, n.1, p.174-182, 2014. Available from: <https:/www.sciencedirect.com/science/ article/pii/S0956713513004106?via\%3Dihub>. Accessed: Jul. 08, 2018. doi: 10.1016/j.foodcont.2013.08.018.

BOLTON, D. J. et al. A small study of Yersinia enterocolitica in pigs from birth to carcass and characterization of porcine and human strains. Food Control. v.33, n.2, p.521-524, 2013. Available from: <https://www.sciencedirect.com/science/article/ pii/S0956713513001618?via\%3Dihub>. Accessed: Jul. 08, 2018. doi: 10.1016/j.foodcont.2013.03.039.

BONARDI, S.et al. Prevalence, characterization and antimicrobial susceptibility of Salmonella enterica and Yersinia enterocolitica in pigs at slaughter in Italy. International Journal of Food Microbiology. v.163, n.2, p.248-257, 2013. Available from: $<$ https://www.ncbi.nlm.nih.gov/pubmed/23603278>. Accessed: Jul. 08, 2018. doi: 10.1016/j.ijfoodmicro.2013.02.012.

BORCH, E. et al. Hazard identification in swine slaughter with respect to foodborne bacteria. International Journal of Food Microbiology. v.30, n.1, p.9-25, 1996. Available from: <https:// www.sciencedirect.com/science/article/pii/016816059600988 9?via\%3Dihub>. Accessed: Jul. 09, 2018. doi: 10.1016/01681605(96)00988-9.

CENTERS FOR DISEASE CONTROL AND PREVENTION(CDC). Yersinia enterocolitica (Yersiniosis). USA, 25 maio
2016. Available from: <https://www.cdc.gov/yersinia/faq.html>. Accessed: Dec. 17, 2018.

DRUMMOND, N. et al. Yersinia enterocolitica: a brief review of the issues relating to the zoonotic pathogen, public health challenges, and the pork production chain. Foodborne Pathogens and Disease. v.9, n.3, p.179-189, 2012. Available from: $<$ https:// www.liebertpub.com/doi/abs/10.1089/fpd.2011.0938>. Accessed: Jul. 09, 2018. doi: 10.1089/fpd.2011.0938.

European Food Safety Authority. EFSA. The European Union summary reporto $\mathrm{n}$ trends and sources of zoonoses, zoonotic agentes and food-borne outbreaks in 2016. EFSA Journal. v.15, n.12, 2017. Available from: <https://www.efsa.europa.eu/en/ efsajournal/pub/5077>. Accessed: Jul. 09, 2018. doi: 10.2903/j. efsa.2017.5077

GERMANO, P. M. L. et al. Higiene e vigilância sanitária de alimentos. 5. ed. São Paulo: Barueri, 2015. p.1077.

LASSOK, B.; TENHAGEN, B. A. From pig to pork: methicillinresistant Staphylococcus aureus in the pork production chain. Journal of Food Protection. v.76, n.6, p.1095-1108, 2013. Available from: $<$ http://jfoodprotection.org/doi/abs/10.4315/0362028X.JFP-12-341 ? code=fopr-site>. Accessed: Jul. 08, 2018. doi:10.\}4315/0362-028X.JFP-12-341.

LAUKANNEN, R. et al. High prevalence of pathogenic Yersinia enterocolitica in pig cheeks. Food Microbiology. v.43, p.50-52, 2014. Available from: <https://www.sciencedirect.com/science/ article/pii/S0740002014000914?via\%3Dihub>. Accessed: Jul. 09, 2018. doi: $10.1016 /$ j.fm.2014.04.016

LAUKANNEN, R. et al. Reduction of enteropathogenic Yersinia in the pig slaughterhouse by using bagging of the rectum. Journal of Food Protection. v.73, n.12, p.2161-2168, 2010. Available from: $<$ http://jfoodprotection.org/doi/pdf/10.4315/0362028X-73.12.2161>. Accessed: Jul. 09, 2018. doi: 10.4315/0362$028 \mathrm{X}-73.12 .2161$

LEIVA, J.; et al. Infecciones por Salmonella y Yersinia. MedicinePrograma de Formación Médica Continuada Acreditado. v.50, n.12, p.2941-2951, 2018. Available from: <https://www. sciencedirect.com/science/article/pii/S0304541218300349>. Accessed: Feb. 19, 2019. doi: 10.1016/j.med.2018.02.011.

MINISTÉRIO DA AGRICULTURA, PECUÁRIA E ABASTECIMENTO. MAPA. Portaria n. 711, de $1^{\circ}$ de novembro de 1995. Aprova as normas técnicas de instalações e equipamentos para abate e industrialização de suínos. Diário Oficial da União, Brasília, DF: 3 Nov. 1995. Available from: <http://www3.servicos. ms.gov.br/iagro_ged/pdf/714_GED.pdf $>$. Accessed: Jun. 27, 2019.

NESBAKKEN, T. et al. Occurrence of Yersinia enterocolitica and Campylobacter spp. in slaughter pigs and consequences for meat inspection, slaughtering, and dressing procedures. International Journal of Food Microbiology. v.80, p.231-240, 2003. Available from: $<$ https://www.sciencedirect.com/science/ article/pii/S0168160502001654?via\%3Dihub>. Accessed: Jul. 08, 2018. doi: 10.1016/S0168-1605(02)00165-4.

PAIXÃO, R. et al. Characterization of Yersinia enterocolitica biotype 1A strains isolated from swine slaughterhouses and markets. The Scientific World Journal. v.2013, 2013. Available from: <https://www.hindawi.com/journals/tswj/2013/769097/>. Accessed: Jul. 09, 2018. doi: 10.1155/2013/769097. 
SABA, R.Z. et al. Isolation of Yersinia enterocolitica in slaughtered swine. Ars Veterinaria. v.29, n.4, 2013. Available from: <http:// arsveterinaria.org.br/index.php/ars/article/view/673>. Accessed: Jul. 09, 2018. doi: 10.15361/2175-0106.2013v29n4p92.

SAMBROOK, J.; RUSSEL, D.W. Molecular cloning: a laboratory manual. New York: Cold Spring Harbor Laboratory Press, 2001.

United States Department of Agriculture, USDA. Livestock and Poultry: World Markets and Trade. 2017. Available from: $<$ https:// apps.fas.usda.gov/psdonline/circulars/livestock_poultry.pdf $>$. Accessed: Feb. 19, 2019.

VAN DAMME, I. et al. Evaluation of the ISO 10273: 2003 method for the isolation of human pathogenic Yersinia enterocolitica from pig carcasses and minced meat. Food Microbiology. v.36, n.2, p.170-175, 2013. Available from: <https://www.sciencedirect. com/science/article/pii/S074000201300110X?via\%3Dihub>. Accessed: Jul. 08, 2018. doi: 10.1016/j.fm.2013.05.007.

VERSALOVIC. J. et al. Genomic fingerprinting of bacteria with repetitive sequence based polymerase chain reaction. Methods in Molecular and Cellular Biology. v.5, p.2540, 1994. Available from: <https://www.researchgate.net/ profile/Sabeen_Raza/publication/8096247_Microbial_DNA Typing_by_Automated_Repetitive-Sequence-Based_PCR/ links/0fcfd4fdb58321f749000000.pdf>. Accessed: Jul. 10, 2018.

WANNET, W.J.B. et al. Detection of pathogenic Yersinia enterocolitica by a rapid and sensitive Duplex PCR assay. Journal of Clinical Microbiology. v.39, n.12, p.4483-4486, 2001. Available from: <https://www.ncbi.nlm.nih.gov/pmc/articles/PMC88570/>. Accessed: Jul. 09, 2018. doi: 10.1128/JCM.39.12.4483-4486.2001. 